\title{
Aspects of environmental quality of life that affect neighbourhood satisfaction in disadvantaged and advantaged Johannesburg communities
}

\author{
Author: Margaret S. Westaway ${ }^{\text {a }}$ \\ Affiliation: ${ }^{a}$ Environment \& Health Research Unit, Medical Research Council and School of Health \\ Systems and Public Health, Faculty of Health Sciences, University of Pretoria, South \\ Africa
}

\begin{abstract}
To ascertain which aspects of environmental quality of life affect neighbourhood satisfaction, a study was conducted with 303 tenure allocated residents of an informal settlement in Soweto, 160 residents of a squatter camp in the same informal settlement, and 375 black and 358 white residents of a middle-class Johannesburg suburb. Respondents rated their satisfaction with housing, public schools, public clinics, public transport, roads, personal safety, street lighting, household refuse removal, jobs, local government and the neighbourhood. Black suburbanites tended to be more satisfied than the other three groups with most of these aspects. Stepwise multiple regression analyses revealed that housing and personal safety accounted for 45 per cent (informal settlement), 21 per cent (squatter camp), 33 per cent (black suburbanites), and 28 per cent (white suburbanites) of the variance in neighbourhood satisfaction. The findings substantiated the importance of housing and personal safety in both disadvantaged and advantaged communities.
\end{abstract}

Keywords: Environmental quality of life; neighbourhood satisfaction; disadvantaged and advantaged communities; Johannesburg

\section{Introduction}

Environmental quality of life, sometimes equated with service provision (M øller \& Jackson, 1997) and customer satisfaction with these services (Social Surveys, 2000), refers to the perceived and experienced quality of life in the broader social, physical and economic environment in the geographic space within which people live (Jeffres \& Dobos,1995; Rogerson et al.,1996). Environmental quality of life includes personal assessments of satisfaction with one's house or dwelling place, schools, health services, safety and security, roads, transport, pollution levels, shopping facilities, cost of living, and jobs or employment opportunities (Cutter, 1982; Jeffres \& Dobos, 1995; Rogerson et al., 1996; M øller \& Jackson, 1997; Social Surveys, 2000; Westaway \& Gumede, 2001; M øller, 2001, 2005; Sirgy \& Cornwell, 2002; Ng, 2005; Westaway, 2006).

Other indicators of environmental quality of life are satisfaction with social aspects such as friendly and cooperative neighbours, good recreational facilities, and sense of privacy at home; physical aspects such as upkeep of homes, landscaping, crowding and noise level, and nearness of neighbourhood facilities; and economic aspects such as property prices, neighbourhood improvements and cost of living in the community (Rogerson et al., 1996; Wee, 2000; Møller, 2001; Parkes et al., 2002; Sirgy \& Cornwell, 2002).

Neighbourhood satisfaction is regarded as a global concept since it is a consequence of assessments of the environmental quality of life aspects relevant to the social, physical, economic and geographic area (Jeffres \& Dobos, 1995). The question of which of these aspects are most important for neighbourhood satisfaction is difficult to answer, because studies vary greatly in the range of variables they cover and their sample population. In some studies, satisfaction or dissatisfaction with housing appears to be the most important predictor of neighbourhood satisfaction (Cutter, 1982; Jeffres \& Dobos 1995; Westaway \& Gumede, 2001; M øller, 2001, 2005; Parkes et al., 2002; Westaway, 2006). Other studies find that safety and security are more important (Rogerson et al., 1996; Mohan \& Twigg, 2007).

Commercial organisations, such as Mercer Human Resort Consulting's Worldwide Quality of Living Survey, annually rank 215 cities as a guide for governments and major companies wanting to place 
employees who are on international assignments. The rankings are based on an aggregated evaluation of 39 criteria for each city, including political, social, economic and environmental factors, personal safety and health, education, transport and other public services. In 2007 Cape Town was ranked at 85 , Johannesburg at 90 and Port Elizabeth at 97 on overall quality of living. For health and sanitation, Cape Town was ranked at 64, Port Elizabeth at 65 and Johannesburg at 70, suggesting that other environmental quality of life factors were influential in decreasing the overall quality of living rankings for these three South African cities.

Other commercial organisations focus mostly on promotion, marketing and tightly restrained demographic characteristics in their evaluation of quality of life (Liner, 2000). They also produce rankings of places that have a significant impact on policy-makers at the national, regional and local levels, as low social, physical and economic rankings are detrimental to the attraction of investments and wealthy migrants (Liner, 2000; Mohan \& Twigg, 2007). In the United Kingdom, place ratings focused initially on economic performance indicators, in line with the prevailing government philosophy that investment should not be devoted to 'stony ground' but should be directed to locations yielding the best economic returns (Champion et al., 1987).

In more recent years, assessment of environmental quality of life and neighbourhood satisfaction is regarded as creating a platform for setting public policies and allocating funds by identifying communities that need an upgrade of services, amenities and revitalisation (Wee, 2000; Parkes et al., 2002; Sirgy \& Cornwell, 2002). A focus on neighbourhoods is a key aspect of the Labour Government's social exclusion strategy in the United Kingdom (Parkes et al., 2002). Instead of defining environmental quality of life, a national UK survey asked people about the attributes of an ideal place to live. The most important were low crime rates, good healthcare and education provision, the cost of living, a range of environmental attractions and amenities, housing and employment opportunities. There were some minor differences in the way residents in different parts of the United Kingdom rated the importance of these attributes (Findlay et al., 1988; Rogerson et al., 1996).

Most studies on environmental quality of life and neighbourhood satisfaction use a 5-point scale for measuring satisfaction with these aspects of the environment (Campbell et al., 1976; Cutter, 1982; M Øller \& Jackson, 1997; Social Surveys, 2000; M øller, 2001, 2005; Sirgy \& Cornwell, 2002; Ng, 2005). Respondents are asked to rate their satisfaction from 1 (very dissatisfied) to 5 (very satisfied) with the various aspects. Cummins and Gullone (2000) have cautioned against the use of 5-point scales, since naming the Likert-scale categories detracts from the interval nature of the derived data. They recommend 11-point scales, with fixed endpoints to increase measurement sensitivity and reduce response-set bias.

Johannesburg has a history of social, physical, economic and geographic inequalities (Beall et al., 2000). For example, the average monthly white household incomes are more than four times higher than those of black households; the former black townships and informal settlements are generally less well developed, in terms of housing, infrastructure and social or recreational facilities, than the previously whites-only suburbs; and deep poverty is concentrated in the squatter encampments (Rogerson, 1996).

In 2000 the Johannesburg Metropolitan Council commissioned Social Surveys (Pty) Ltd to undertake a survey of customer satisfaction with service delivery (an aspect of environmental quality of life) in the 11 new regions of Greater Johannesburg. Inadequate access to services, or no services at all, was more frequent in black communities, with informal settlements and squatter camps being the most problematic. Their major service issues were electricity, water, job creation, toilets, health services and street lighting (Social Surveys, 2000). Inadequate maintenance of services (road repairs and street lighting) or a breakdown in service provision (delays in response from emergency services) led to dissatisfaction in Johannesburg's suburbs (Social Surveys, 2000).

The City of Johannesburg has planned to get rid of informal settlements and squatter camps to make way for serviced stands owned by people who have title deeds to their properties (site tenure), and upgrading onsite (Thale, 2002). Unfortunately, the migration of black South Africans into the city in search of work has placed an enormous burden on housing, infrastructure and service delivery. This, coupled with the housing backlog, high unemployment rates (estimated at 57 per cent in 2002) and 
non-payment for services means that for many black South Africans there is no alternative but to live in informal settlements and squatter camps (Westaway, 2006).

The second decade of South African democratic governance has seen the emergence of a young black middle class who have been able to move to previously whites-only suburbs, with superior services to those of the townships, informal settlements and squatter camps (Beall et al., 2000), to be educated at previously whites-only schools, and to find employment in previously whites-only occupations. The question remains as to whether residential area is a reflection of socio-demographic characteristics and whether residential area and/or race affect perceptions and experiences of environmental quality of life and neighbourhood satisfaction. To answer this question, a study was conducted in a middle-class suburb and a black informal settlement and squatter camp in Soweto to ascertain similarities and differences in socio-demographic characteristics, to determine the effects of residential area and/or race on environmental quality of life and neighbourhood satisfaction, and to investigate the most important environmental quality of life predictors of neighbourhood satisfaction.

\section{Methods}

\subsection{Research design}

A cross-sectional analytical research design was used. Comparisons were made between four groups (black and white suburbanites, and tenure allocated and squatter camp residents of an informal settlement) on socio-demographic characteristics, satisfaction with 10 environmental quality of life aspects, overall environmental quality of life and a global measure of neighbourhood satisfaction.

\subsection{Measures}

Information was obtained on socio-demographic characteristics (age, gender, years of schooling, further academic qualifications, marital status, duration of residence in the area, household size, employment status and occupational status). Ten single items, initially adapted from Jeffres and Dobos (1995) but used since 1999 in South Africa (Westaway \& Gumede, 2001; Westaway, 2006), measured satisfaction with the 10 environmental quality of life aspects: own house or dwelling, public schools, public clinics, public transport, roads, personal safety, street lighting, household refuse removal, employment opportunities and local government. One item measured neighbourhood satisfaction. Average scores for these 10 items ranged from 1.6 (jobs) and 6.3 (transport) for squatter camp residents to 1.9 (jobs) and 7.8 (transport) for informal settlement residents in 2002 (Westaway, 2006). A recent study from Nigeria (Ejechi \& Ejechi, 2007) used seven of these 10 environmental quality of life aspects and found that average scores for satisfaction with transport ranged from 4.7 to 6.2 in four small cities and one large city in the Western Niger Delta.

In accordance with Cummins and Gullone's (2000) recommendation, respondents were asked to rate their level of satisfaction on an 11-point scale, ranging from 0 (completely dissatisfied) to 10 (completely satisfied), with their own house or dwelling, public schools, public clinics, public transport, roads, personal safety, street lighting, household refuse removal, employment opportunities and local government. Ratings for the 10 aspects were summed and averaged for an overall environmental quality of life score. In 2002, the average score was 4.4 for informal settlement residents and 3.4 for squatter camp residents (Westaway, 2006). However, scores on neighbourhood satisfaction were slightly higher at 5.0 for informal settlement residents and lower at 3.2 for squatter camp residents than on overall environmental quality of life (Westaway, 2006). Ejechi and Ejechi (2007) reported an overall environmental quality of life score between 3.4 and 4.1 for their seven aspects, indicative of similarities between these South Africans and their samples of Nigerians. To compare quantitative and qualitative data in the current study, respondents recorded their reasons for high or low ratings.

\subsection{Sampling}


There are 12 blocks in this informal settlement in Soweto, with approximately 7000 formal stands with one or more structures on each. A squatter camp has been set up in Block 9 as a temporary housing measure. All of the stands are numbered, even in the squatter camp. It is estimated that there are approximately 60000 people living in the settlement. In 1999, two random samples of 250 stand numbers each were drawn from Blocks 1-12 (site tenure allocated), and a random sample of 250 stand numbers from the squatter area in Block 9 of the settlement, in accordance with Daly et al.'s methodology (1991:425-7). In 1999, a structured questionnaire, with a consent form, was administered to 448 site tenure allocated residents and 214 squatter camp residents. The same questionnaire was administered to the same residents annually (Westaway, 2006). In 2003, the questionnaire was administered to 303 site tenure and 160 squatter camp residents, 70 per cent of the original sample, indicating small losses to follow-up.

This middle-class Johannesburg suburb lies approximately 50 kilometres to the northeast of the informal settlement and comprises 10 sub-areas, with different social, physical and economic attributes. For example, orthodox Jewish residents prefer to be able to walk to their place of worship, which restricts them to residing within walking distance. In some sub-areas, individual residences on large stands predominate, whereas flats are more common in other sub-areas. There is also a barracks for the South African Police Service. Access by public transport to shops and amenities is only available during peak-hour traffic. These differences necessitated drawing a stratified random sample of 850 residences.

\subsection{Procedure}

A research coordinator and 40 multilingual fieldworkers, both black and white, were recruited, trained and paid to conduct the interviews. Interviewing in the informal settlement and squatter camp was completed in November 2003. Due to South Africa's lengthy holiday period in December and January, and the necessity of providing baseline data prior to the introduction of an integrated service delivery programme, interviews in the middle-class suburb were completed in March 2004.

As part of a longitudinal study (starting in 1999) on health, well-being and quality of life in an informal settlement in Soweto (Westaway, 2006), data on a wide range of variables were collected annually from the same residents. For the purpose of this analysis, only data collected in 2003 on basic demographic characteristics, rated satisfaction with the 10 environmental quality of life aspects, rated neighbourhood satisfaction and reasons for high or low levels of satisfaction were used. Before the integrated service delivery programme was initiated, data on the same variables were collected in a middle-class Johannesburg suburb.

\subsection{Data analysis}

All data were analysed with SPSS (version 14). Descriptive statistics were the first step for data analysis. $t$-Tests, one-way analysis of variance with Bonferroni adjustments for multiple comparisons, chi-squared tests and Pearson product-moment correlation coefficients were used to compare the socio-demographic characteristics of black and white suburbanites, and informal settlement and squatter camp residents. The $t$-tests, analyses of variance, chi-squared tests and Pearson productmoment correlation coefficients were used to determine the effects of residential area and race on the 10 environmental quality of life aspects, overall environmental quality of life and neighbourhood satisfaction. Separate stepwise multiple regression analyses by group were conducted on the data to investigate the environmental quality of life predictors of neighbourhood satisfaction.

\section{Results}

\subsection{Socio-demographic characteristics}

The data came from 1196 respondents: 303 from the informal settlement, 160 from the squatter camp in the same informal settlement, and 375 black and 358 white residents of the middle-class suburb. Ages ranged from 18 to 93 years ( mean $=39.4$, standard deviation $[S D]=13.5$ ). The black 
suburbanites were significantly younger, had fewer years of education, and had lived in the suburb for a shorter period of time than the white suburbanites $(p<0.001)$, but came from same-size households (Table 1). Seventy-five per cent of the black and 92 per cent of the white suburbanites had completed high school. Comparing further academic qualifications, the black suburbanites had a certificate (48 per cent) and the white suburbanites had a degree ( 41 per cent). Both groups were equally likely to be employed $(p>0.05)$. The majority (66 per cent) of the black suburbanites had lived in Johannesburg's townships before taking up residence in this suburb.

\section{Demographic}

Table 1: Selected demographic characteristics of the sample

Age

Years of

education Informal settlement residents Mean 40.7

4.3

\section{SD}
Squatter camp residents

Mean SD

Black
suburbanites
Mean SD

32.7
White
suburbanites

Mean SD

$44.4 \quad 15.6$

$\begin{array}{llll}11.2 & 1.8 & 11.8 & 0.7\end{array}$

Years of

residence

7.6

3.6

2.6

7.0

1.8

6.0

6.1

12.7

12.6

Household size

1.9

3.8

1.8

$3.5 \quad 2.4$

3.3

The black suburbanites were younger, and had more years of education and post-school further academic qualifications than the informal settlement and squatter camp residents $(p<0.001)$ (Table 1). Only 24 per cent of the informal settlement and 18 per cent of the squatter camp residents had completed high school; 11 per cent of the informal settlement and 3 per cent of the squatter camp residents had a certificate. The black suburbanites had lived in this suburb for a shorter period of time and came from smaller households $(p<0.001)$ than the informal settlement residents (Table 1$)$, indicative of their more advantaged economic status. The informal settlement residents had more years of education, had lived there longer $(p<0.01)$, and came from larger households $(p=0.05)$ than the squatter camp residents (Table 1).

Although there were educational differences between these three groups, it is noteworthy that 8 years of education constitutes completion of primary school (informal settlement and squatter camp residents), whereas 12 years is completion of high school (the majority of the black suburbanites). Age was negatively related to education for the residents of the informal settlement, squatter camp and black suburbanites, but not the white suburbanites, indicating a lack of access to educational opportunities for older black South Africans.

Only 47 per cent of the informal settlement and 40 per cent of the squatter camp residents were employed, compared with 76 per cent of the black and 78 per cent of the white suburbanites. Statistics South Africa (Lehohla, 2006:43-61) estimated the unemployment rate in March 2004 as 34 per cent for black South Africans and 5 per cent for white South Africans. This estimate is based on whether respondents are looking for work, and is most probably an underestimate. Previous research has shown that the unemployment rate in informal settlements and squatter camps lies between 54 and 57 per cent (Westaway, 2006). The black suburbanites in this study were more likely to be employed in higher-status occupations than the informal settlement and squatter camp residents. For example, the black suburbanites' occupations ranged from accountancy, human resources and information technology, at the upper level, to shop assistant, security guard and domestic work, at the lower level. In contrast, the majority of the informal settlement and squatter camp residents were employed, if employed at all, in lower-status occupations such as cleaning, gardening and domestic work.

\subsection{Environmental quality of life}

All four groups tended to rate their satisfaction with jobs, local government and public clinics below the mid-point (Figure 1). Respondents stated that job creation in the City of Johannesburg was given a low priority and too few jobs were available. They also said that if there were more jobs there would 
be less crime. Their perception was that local government was doing nothing, except before municipal elections. Public clinics were considered to be dirty, with poor staff service, a lack of medicine, overcrowded and only for women and children. Satisfaction ratings for public clinics ranged between 4.0 and 4.7, very similar to the ratings for the five Nigerian cities, with a range between 3.0 and 4.3 (Ejechi \& Ejechi, 2007).

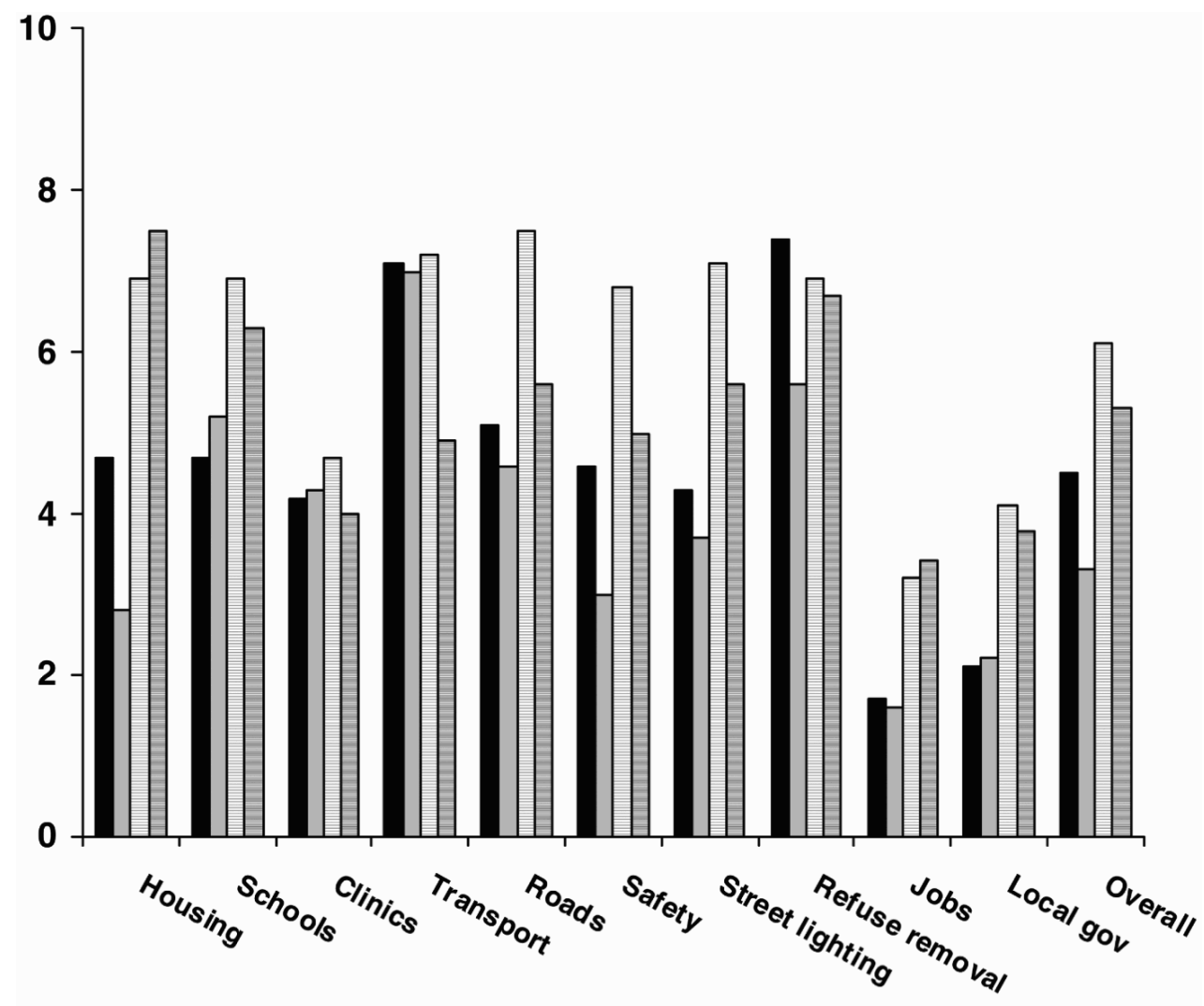

$\square$ Informal settlement $\square$ Squatter camp $\square$ Black suburbanites $\square$ White suburbanites

Figure 1:. Average satisfaction scores on the 10 environmental quality of life aspects and overall environmental quality of life: informal settlement, squatter camp, black suburbanites and white suburbanites

The black suburbanites were very satisfied with their housing (6.9), public schools (6.9), public transport (7.2), roads (7.5), personal safety (6.8), street lighting (7.1) and refuse removal (6.9). In their comments they mentioned the more spacious accommodation and higher building standards than were available in the townships, the higher educational standards in this suburb than those of township schools, buses and taxis available to take them to work and back again, roads better maintained than in the townships, private security companies to ensure their safety, and regular refuse removal even on public holidays.

The white suburbanites were very satisfied with their housing (7.5), but not satisfied with public transport (4.9), roads (5.6), personal safety (5.0) and street lighting (5.6). They said their houses were spacious and their gardens well maintained, but public transport was unavailable outside peak hours or was unsafe, the roads had too many potholes, they could not walk in the streets for fear of being mugged, they were terrified of armed robberies, and the street lights were not being repaired.

The squatter camp residents were very satisfied with their transport (7.0), but only somewhat satisfied with their housing (2.8), personal safety (3.0) and street lighting (3.7). They said they did not want to live there, with no water, toilets or electricity, they had been forgotten by the City, the crime rate was very high and the police never investigated crimes, they could not leave their shacks at night for fear 
of being stabbed, shot, raped or murdered, and there were no street lights in their area. The informal settlement residents were very satisfied with public transport (7.1) and refuse removal (7.4). They said that public transport was readily available and within their economic means, and there was a weekly regular removal of household refuse, with a plastic bag supplied for their rubbish bin (Figure 1).

The average overall environmental quality of life scores were $4.5(S D=1.2)$ for informal settlement residents, $3.3(\mathrm{SD}=1.2)$ for squatter camp residents, $6.1(\mathrm{SD}=1.2)$ for black suburbanites and 5.3 $(S D=1.2)$ for white suburbanites. There were significant differences $(p<0.001)$ between the groups on overall environmental quality of life, with the black suburbanites having the highest environmental quality of life and the squatter camp residents the lowest.

\subsection{Neighbourhood satisfaction}

Average scores for neighbourhood satisfaction were $6.3(S D=2.9)$ for informal settlement residents, $4.8(\mathrm{SD}=3.0)$ for squatter camp residents, $7.2(\mathrm{SD}=2.6)$ for black suburbanites and $6.6(\mathrm{SD}=2.3)$ for white suburbanites. The black suburbanites were more satisfied with their neighbourhood than the white suburbanites and the residents of the informal settlement and the squatter camp $(p<0.001)$. However, the informal settlement residents and the white suburbanites were equally satisfied with their neighbourhoods (Figure 2). These similarities suggested that limited access to services and satisfaction of basic needs (Veenhoven, 1996) are not the only factors affecting neighbourhood satisfaction.

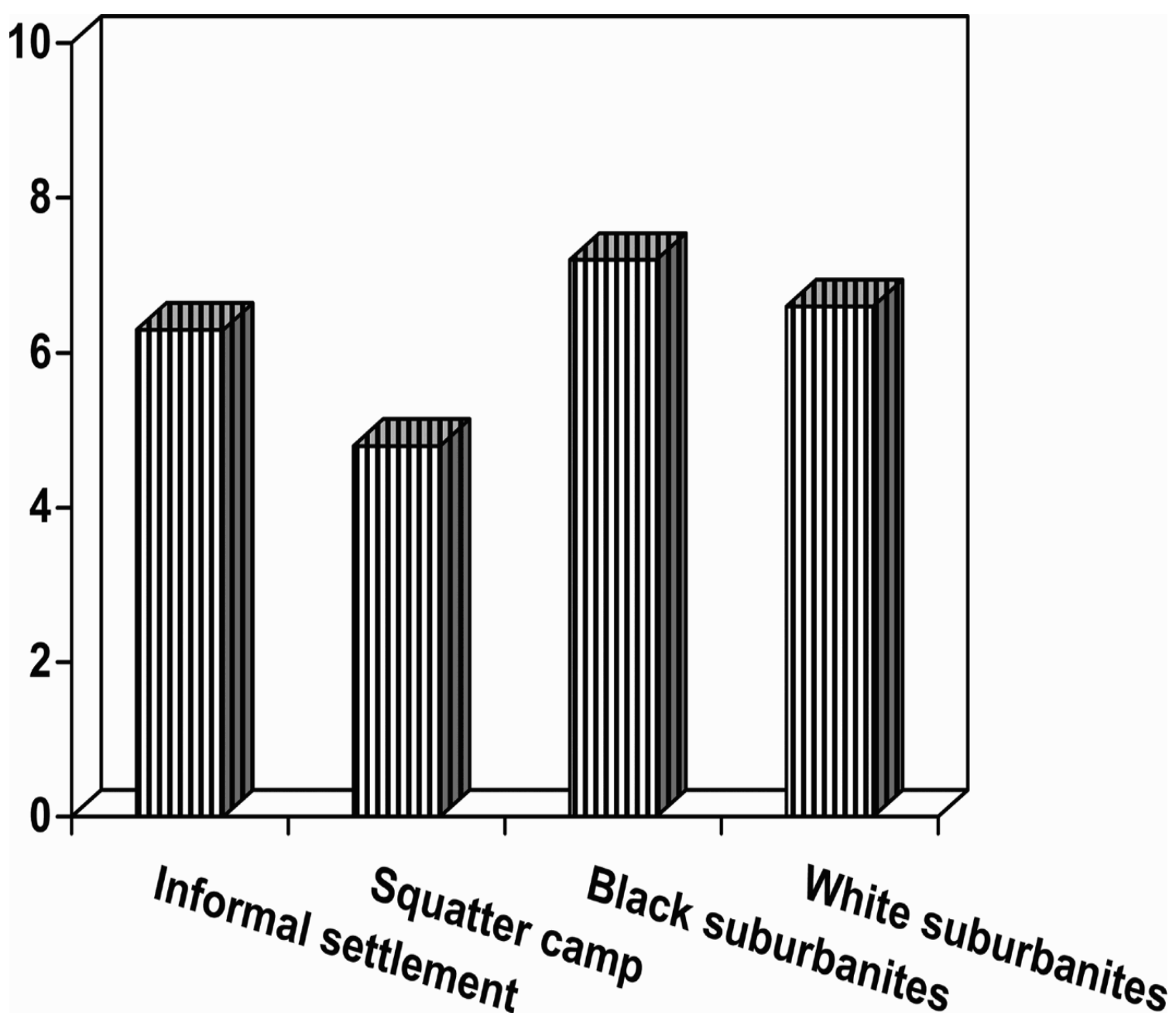

Figure 2:. Average scores on neighbourhood satisfaction: informal settlement, squatter camp, black suburbanites and white suburbanites 


\subsection{Predictors of neighbourhood satisfaction}

Table 2 shows that 48 per cent of the variance in neighbourhood satisfaction was explained by three environmental quality of life aspects for informal settlement residents, 26 per cent for squatter camp residents, 34 per cent for black suburbanites, and 31 per cent for white suburbanites. For the informal settlement and squatter camp residents and the white suburbanites, the most important predictor of neighbourhood satisfaction was housing, whereas for the black suburbanites it was personal safety. These quantitative findings substantiated the qualitative comments cited above. For all four groups, housing and personal safety were important predictors of neighbourhood satisfaction; this was similar to previous US, UK and South African findings (Campbell et al., 1976; Cutter, 1982; Rogerson et al., 1996; Westaway \& Gumede, 2001; M øller, 2001, 2005; Parkes et al., 2002; Westaway, 2006). The negative beta coefficient for personal safety for squatter camp residents attests to their perceptions of being extremely unsafe in their neighbourhood (Westaway, 2006).

Table 2: Predictors of neighbourhood satisfaction for informal settlement residents, squatter camp residents, and black and white suburbanites

Informal settlement residents $(n=303) \quad$ Squatter camp residents $(n=160)$

$\begin{array}{lrcccrcc}\text { Predictor } & \text { Adjusted } \boldsymbol{R}^{\mathbf{2}} & \text { Beta } & \boldsymbol{t} & \text { Predictor } & \text { Adjusted } \boldsymbol{R}^{\mathbf{2}} & \text { Beta } & \boldsymbol{t} \\ \text { Housing } & 0.30 & 0.39 & \text { 8.61 Housing } & 0.12 & 0.58 & 7.35 \\ \text { Safety } & 0.15 & 0.37 & \text { 8.54 Safety } & 0.09 & -0.35 & 4.49 \\ \text { Transport } & 0.03 & 0.20 & 4.38 \text { Schools } & 0.05 & 0.37 & 4.86 \\ \text { Total } & 0.48 & & \text { Total } & 0.26 & & \end{array}$

$F(3,299)=93.18, p<0.001$

$F(3,156)=19.80, p<0.001$

Black suburbanites $(n=375)$

White suburbanites $(n=358)$

Predictor

Adjusted $R^{2}$ Beta $t \quad$ Predictor

Adjusted $\boldsymbol{R}^{\mathbf{2}}$ Beta $\boldsymbol{t}$

Safety

$\begin{array}{lll}0.27 & 0.39 & 8.21 \text { Housing }\end{array}$

$\begin{array}{lll}0.18 & 0.34 & 7.29\end{array}$

Housing

$\begin{array}{lll}0.06 & 0.25 & 5.52 \text { Safety }\end{array}$

$\begin{array}{lll}0.10 & 0.28 & 5.90\end{array}$

Street lighting

$\begin{array}{lll}0.01 & 0.13 & 2.78 \text { Local government }\end{array}$

$\begin{array}{lll}0.03 & 0.17 & 3.71\end{array}$

Total

0.34

Total

0.31

$F(3,371)=64.43, p<0.001$

$F(3,354)=53.73, p<0.001$

\section{Discussion and conclusions}

The differences between the black suburbanites and the informal settlement and squatter camp residents in age, education and employment status suggest that these black suburbanites are more economically advantaged than their poorer counterparts. It would appear that they have been educated at previously whites-only schools, are employed in previously whites-only occupations and have moved to previously whites-only suburbs. In contrast, the informal settlement and squatter camp residents tend to be poorly educated, have had few opportunities in life, and face major challenges in providing for themselves and their families (Beall et al., 2000).

The low level of satisfaction with jobs, local government and public clinics for all four groups implies that the City of Johannesburg needs to focus on job creation, service delivery and public health. It is 
to be hoped that, in the run-up to South Africa's 2010 World Cup, employment opportunities for all Johannesburg's residents will be more accessible. Although the City of Johannesburg is determined to address the needs of its under-serviced areas, such as Durban (M øller, 2001), it faces major crises in service delivery and public health, because of non-payment for rates and services, illegal electricity and water connections, a lack of capacity, poor staff morale, and a high staff turnover of doctors, nurses and teachers (Westaway, 2006). This crisis cannot be resolved without major investments in infrastructure and personnel, and the creation of a culture of payment for rates and services.

Suburbia, for black residents, most certainly provides better services than the former black townships, informal settlements and squatter camps, with their poor infrastructure and educational, health, social and recreational facilities (Rogerson, 1996; Beall et al., 2000). It is possible that these high satisfaction levels will decline over time, as people adapt to both positive and negative life experiences (Brickman et al., 1978). In contrast, for white residents suburbia appears to have deteriorated, most probably due to perceptions of inadequate maintenance of services, breakdowns in service provision, and the unavailability of services such as public transport outside peak periods (Social Surveys, 2000).

The high levels of satisfaction with public transport expressed by the three black sub-samples were comparable with those expressed by residents of the five Nigerian cities affected by the oil and gas industry (Ejechi \& Ejechi, 2007). However, like the squatter camp residents in the present study, the Nigerian residents were not satisfied with housing, refuse removal and street lighting. According to Ejechi and Ejechi (2007), the high population density and congestion are responsible for these findings.

The City of Johannesburg established a Metropolitan Police Service in March 2001 to reduce the high crime rates and improve the previous ineffective, corrupt policing (Social Surveys, 2000). Both the black and the white suburbanites were more likely to use private security companies for their personal safety, indicating that the Metropolitan Police Service appears to be losing the battle against crime. More importantly, the concerns expressed by squatter camp residents about their personal safety reveal that squatter camps appear to be 'no-go' areas for visible, effective policing.

The average overall environmental quality of life scores for informal settlement and squatter camp residents were very similar to those reported for 2002 (Westaway, 2006). The scores were below the midpoint of the scale, comparable with those of the Nigerian study. Living in one of the five Nigerian cities studied by Ejechi and Ejechi (2007) seems to be as detrimental to environmental quality of life as it is for South African informal settlement and squatter camp residents. Although the white suburbanites had a poorer perception of their environmental quality of life than the black suburbanites, they were more likely to perceive a better environmental quality of life than informal settlement and squatter camp residents. This suggests that suburbia in South Africa tends to make a more positive impact on residents' perceptions of their environmental quality of life.

As expected, the group from the squatter camp were the least satisfied with their neighbourhood, providing support for M Øller's (2001) findings in Durban. In contrast with M øller's (2001) findings in Durban, informal settlement residents were more satisfied with their neighbourhood in 2003 than in 2002, since their average satisfaction scores increased from 5.0 to 6.3 . This finding suggests that the City of Johannesburg's policy of allocating tenure and upgrading on-site is perceived as a positive improvement to the neighbourhood, and is similar to findings in the United Kingdom and the USA (Parkes et al., 2002; Sirgy \& Cornwell, 2002; Mohan \& Twigg, 2007).

The reason the white suburbanites' level of dissatisfaction with their neighbourhood matched that of the informal settlement residents may be their negative perceptions of social, physical and economic neighbourhood improvements for white suburbanites. The black suburbanites were the most positive about their neighbourhood, which suggests that their perceptions of neighbourhood improvements differed from those of their white counterparts. In the main, the findings tend to support the effect of residential area rather than race on environmental quality of life and neighbourhood satisfaction, which suggests that integrated, rather than segregated, multiracial neighbourhoods promote a better environmental quality of life and more satisfaction with neighbourhood. 
Although there were differences between the groups on the predictors of neighbourhood satisfaction, the current findings support the idea that environmental quality of life aspects affect neighbourhood satisfaction both cross-culturally and cross-racially (Cutter, 1982; Jeffres \& Dobos, 1995; M øller, 2001; Westaway, 2006). Housing was rated more important by the informal settlement residents than by the squatter camp residents, probably because of the City of Johannesburg's housing policy of upgrading on-site in informal settlements, but not in squatter camps (Thale, 2002).

It was concluded that the findings substantiated the following: socio-economic differences between residential areas; a high unemployment rate, particularly among poorly educated black South Africans; perceptions of a lack of delivery at a local level, especially on job creation and the provision of effective local government; the crisis in public health services, which over 90 per cent of the black population rely on; concerns about personal safety, in the absence of the economic means to pay for private security; the very real housing and personal safety needs of squatter camp residents; the effect of residential area, rather than race, on environmental quality of life and neighbourhood satisfaction; and the importance of housing and personal safety in predicting neighbourhood satisfaction in advantaged and disadvantaged Johannesburg communities.

\section{References}

- 1. BEALL, J, CRANKSHAW, O and PARNELL, S (2000) Local government, poverty reduction and inequality in Johannesburg. Environment \& Urbanization 12 , pp. 107-122.

- 2. BRICKMAN, P, COATES, D and JANOFF-BULLMAN, R (1978) Lottery winners and accident victims: is happiness relative?. Journal of Personality and Social Psychology 36 , pp. 917-927.

- 3. CAMPBELL, A, CONVERSE, P E and RODGERS, W L (1976) The quality of American life: perspectives, evaluations, and satisfactions Russell Sage Foundation, New York

- 4. CHAMPION, A G , GREEN, A E , OWEN, D J , ELLIN, D J and COOMBES, M G (1987) Changing places Edward Arnold, London

- 5. CUMMINS, R A and GULLONE, E (2000) Why we should not use 5-point Likert scales: the case for subjective quality of life measurement. Proceedings of the Second International Conference on Quality of Life in Cities, 21st Century QOL (ICQOLC) Singapore National University of Singapore 1, Singapore

- 6. CUTTER, S (1982) Residential satisfaction and the suburban homeowners. Urban Geography 3 , pp. 315-327.

- 7. DALY, L E, BOURKE, G J and MCGILVRAY, J (1991) Interpretation and uses of medical statistics Blackwell Scientific Publication, Oxford

- 8. EJECHI, E O and EJECHI, B O (2007) Safe drinking water and satisfaction with environmental quality of life in some oil and gas industry impacted cities of Nigeria. Social Indicators Research 85 , pp. 211-222.

- 9. FINDLAY, A, ROGERSON, R and MORRIS, A (1988) Where to live in Britain in 1988. Cities 10 , pp. 268-276

- 10. JEFFRES, L W and DOBOS, J (1995) Separating people's satisfaction with life and public perceptions of the quality of life in the environment. Social Indicators Research $\mathbf{3 4}$, pp. 181211.

- 11. LEHOHLA, P (2006) Stats in brief, 2006 Statistics South Africa, Pretoria

- 12. LINER, E B (2000) Proceedings of the Second Conference on Quality of Life in Cities, 21st Century QOL (ICQOLC) Singapore Quality of life measures, practices, and policies in U.S. cities 1

- 13. MOHAN, J and TWIGG, L (2007) Sense of place, quality of life and local socioeconomic context: evidence from the Survey of English Housing, 2002/03. 10 , pp. 2029-2045.

- 14. $M \varnothing L L E R, V(2001)$ Monitoring quality of life in cities: the Durban case. _18, pp. 217-238.

- 15. M ØLLER, V (2005) Resilient or resigned? Criminal victimization and quality of life in South Africa. Social Indicators Research 72 , pp. 263-317

- 16. M ØLLER, V and JACKSON, A (1997) Perceptions of service delivery and happiness. Development Southern Africa 14 , pp. 169-184. 
- 17. NG, S L (2005) Subjective residential environment and its implications for quality of life among university students in Hong Kong. Social Indicators Research 71, pp. 467-489.

- 18. PARKES, A, KEARNS, A and ATKINSON, R (2002) What makes people dissatisfied with their neighbourhoods?. 39 , pp. 2413-2438.

- 19. ROGERSON, C M (1996) Urban poverty and the informal economy in South Africa's economic heartland. Environment and Urbanization 8 , pp. 167-181

- 20. ROGERSON, R , FINDLAY, A, MORRIS, A and PADDISON, R (1996) Class, consumption and quality of life. Progress in Planning 45, pp. 1-66

- 21. SIRGY, M J and CORNWELL, T (2002) How neighbourhood features affect quality of life. Social Indicators Research 59 , pp. 79-114

- 22. SOCIAL SURVEYS (October 2000) Johannesburg Metropolitan Council attitudinal survey

- 23. THALE, T (2002) Jo'burg plans to end informal settlements -

- 24. VEENHOVEN, R (1996) Developments in satisfaction research. Social Indicators Research 37 , pp. 1-46

- 25. WEE, H L (2000) Proceedings of the Second Conference on Quality of Life in Cities, 21st Century QOL (ICQOLC) Singapore Quality of life assessment: is quality of place an appropriate proxy? 1

- 26. WESTAWAY, M S (2006) A longitudinal investigation of satisfaction with personal and environmental quality of life in an informal South African housing settlement: Doornkop, Soweto. Habitat International 30 , pp. 175-189.

- 27. WESTAWAY, M S and GUMEDE, T (2001) Satisfaction with personal and environmental quality of life: a black South African informal settlement perspective. Curationis 24 , pp. 28-34 